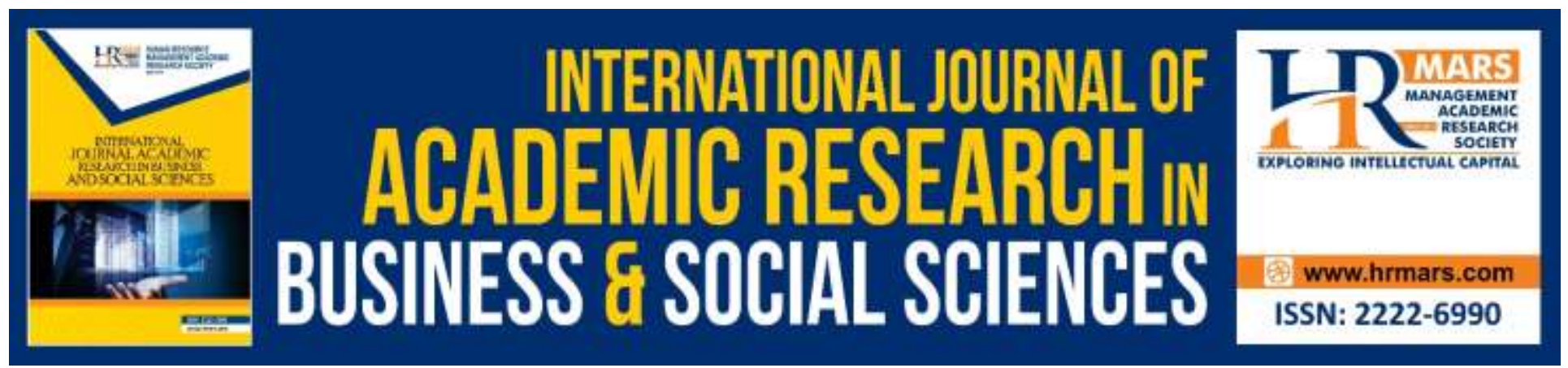

\title{
Digital Literacy, Business Uncertainty \& Economic Performance: An Empirical Study of Small Businesses in Sri Lanka
}

Ranatunga R.V.S.P.K., Priyanath H.M.S., Megama R.G.N.

To Link this Article: http://dx.doi.org/10.6007/IJARBSS/v10-i5/7171

DOI:10.6007/IJARBSS/v10-i5/7171

Received: 02 March 2020, Revised: 09 April 2020, Accepted: 23 April 2020

Published Online: 02 May 2020

In-Text Citation: (Ranatunga et al., 2020)

To Cite this Article: Ranatunga, R.V.S.P.K., Priyanath, H.M.S., \& Megama, R.G.N. (2020). Digital Literacy, Business Uncertainty \& Economic Performance: An Empirical Study Of Small Businesses In Sri Lanka. International Journal Of Academic Research In Business And Social Sciences, 10(5), 50-76.

Copyright: (C) 2020 The Author(s)

Published by Human Resource Management Academic Research Society (www.hrmars.com)

This article is published under the Creative Commons Attribution (CC BY 4.0) license. Anyone may reproduce, distribute, translate and create derivative works of this article (for both commercial and non-commercial purposes), subject to full attribution to the original publication and authors. The full terms of this license may be seen

at: http://creativecommons.org/licences/by/4.0/legalcode

Vol. 10, No. 5, 2020, Pg. $50-76$

http://hrmars.com/index.php/pages/detail/IJARBSS

JOURNAL HOMEPAGE

Full Terms \& Conditions of access and use can be found at http://hrmars.com/index.php/pages/detail/publication-ethics 


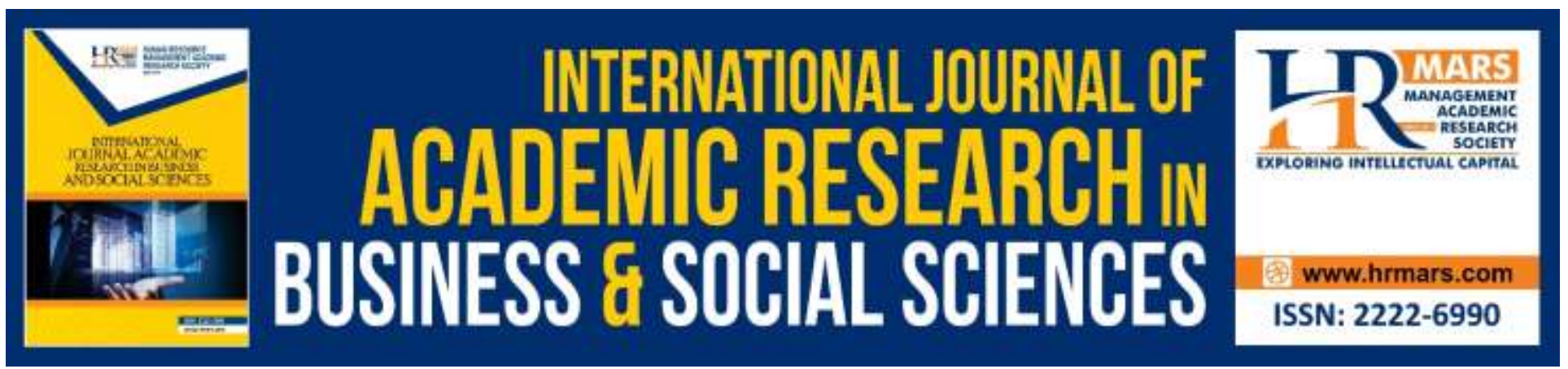

\title{
Digital Literacy, Business Uncertainty \& Economic Performance: An Empirical Study of Small Businesses in Sri Lanka
}

\author{
Ranatunga R.V.S.P.K. ${ }^{1}$, Priyanath H.M.S. ${ }^{2}$, Megama R.G.N. ${ }^{3}$ \\ ${ }^{1}$ Centre for Computer Studies, Sabaragamuwa University of Sri Lanka, Belihuloya. Sri Lanka, \\ ${ }^{2}$ Department of Economics and Statistics, Sabaragamuwa University of Sri Lanka, Belihuloya. Sri \\ Lanka, ${ }^{3}$ Faculty of Applied Sciences, University of Sri Jayewardenepura. Nugegoda. Sri Lanka. \\ Email: spkr@ccs.sab.ac.lk
}

\begin{abstract}
The study attempts to investigate empirically how Digital Literacy (DL) affects the Business Uncertainty and Economic Performance particularly Small Enterprises (SEs) in Sri Lankan. The data were collected from 110 owners of SEs, conducting face to face interviews and analysed using Partial Least Squares-Structural Equation Modelling. The results discovered that the different dimensions of DL have a negative impact on business uncertainty and positive effects on the economic performance of SEs. Thus, the study recognized that the DL highly affects the minimization of business uncertainty and thereby increases the economic performance of SEs in Sri Lanka. Further, the results confirmed that the business uncertainty has a strong significant mediate effect on the relationship between DL and the economic performance of SEs in Sri Lanka. The study strongly recommends SEs to strengthen the digital technologies which play a dominant role to enhance economic sustainability minimizing the behavioural and environmental uncertainty. Thus, the study provides useful insight into the role of DL on the economic performance of SEs minimizing business uncertainty in Sri Lanka from a novel perspective.
\end{abstract}

Keywords: Digital Literacy, Business Uncertainty, Economic Performance, Small Businesses

\section{Introduction}

Most of the scholars and organizations around the world have paid more attention in the development of SEs of a country since SEs are playing vital role in the economic growth and the development of a country and consequently this is given more consideration on national planning and development of a country (Abdullah \& Beal, 2003; Henderson \& Weiler, 2009; Jamil \& Mohamed, 2011; Olawale, 2018; Organization of Economic Co-operation and Development (OECD), 2017). SES lead to introduce innovative products, services and business functionalities, make new employment opportunities, reduce the poverty, income inequality and inflation of the countries (Kayanula \& Quartey, 2000; Prasad, Tata \& Guo, 2012; Priyanath \& Premarathne, 2014; Singh, Garg \& Deshmukh, 
2010). Therefore, SEs of a country are considered as the engine of economic growth (Henderson \& Weiler, 2009).

Although SEs have a significant role in the economy, worldwide studies have stated that the performance of SEs is low in developing countries (Abor \& Quartey, 2010; Olawale, 2018). SEs unable to contribute their valuable share effectively to the national development and consequently, it is not been measured up in the developed countries (Organization of Economic Co-operation and Development (OECD), 2017). Some researchers mentioned that the contribution of SEs to the GDP has remained below as expected and their failure rate is high in the developing countries due to the various constraints and challenges such as capital, human as well as market based, legal or regulatory effects and since on this situation, the survive in the market with economic sustainability is a significant problem (Abor \& Quartey, 2010; Gbandi \& Amissah, 2014; Yoshino \& Taghizadeh-Hesary, 2016; Petković, Jäger \& Sašić 2016).

SEs are small and infant in the business field, they don't have sufficient knowledge, and experiences in the business field (Carmel \& Nicholson, 2005; Nooteboom, 1993). Therefore, they do not have the experiences and capacity to collect and evaluate information to forecast the regular variations of the complex business environment and as a result their decision-making power is very bounded (Yenidogan, 2013). Consequently, SEs fail to safeguard the hazards from the opportunism of exchange partners (Agwu \& Emeti, 2014) and the result is the increase of Transaction Cost (TC) and the failure rate (Carmel \& Nicholson, 2005; Nooteboom, 1993).

SEs need to get proper accurate decisions to avoid various inappropriate opportunistic influences which are raised on financial and environmental factors and conversely, it is the way of plastering the above uncertainty and furthermore the human has less rational ability and it again increases the inability of covering the uncertainty effects (Priyanath, 2017; Priyanto et al., 2014). The decision theories which can be used to make such optimum decisions are mainly depended on the availability of adequate, reliable and timely information (James, 2007; Kenneth \& Jane, 2013). Not like the past, but now the digital technologies provide adequate facilities to disseminate such information among transaction parties (Kenneth \& Jane, 2013). However, the problem is that the quantifiably measure the extent of literacy and use of these technologies to obtain such valuable information to avoid the uncertainty barriers and finally, facing less opportunism to make the success of economic performance by minimizing the TC.

\section{Objectives}

The main objective of this research is to explore the effect of digital literacy on business uncertainty and economic performance particularly SEs in Sri Lanka.

Specific objectives of this study are;

$>$ To study the effect of digital infrastructure on business uncertainty and economic performance of SEs in Sri Lanka

$>$ To examine the impact of digital application on business uncertainty and economic performance of SEs in Sri Lanka

$>$ To find out the role of digital policy on business uncertainty and economic performance of SEs in Sri Lanka

$>$ To determine the strength of digitally enabled human resources on business uncertainty and economic performance of SEs in Sri Lanka 
INTERNATIONAL JOURNAL OF ACADEMIC RESEARCH IN BUSINESS AND SOCIAL SCIENCES

Vol. 10, No. 5, May, 2020, E-ISSN: 2222-6990 @ 2020 HRMARS

$>$ To calculate the mediate power of business uncertainty on the relationship between digital literacy and economic performance of SEs in Sri Lanka

\section{Theoretical Background}

Digital Literacy: ICT literacy has been defined by the American Library Association (ALA) (2006) with four aspects; a). The ability to recognize when information is needed; b). The ability to locate the needed information; c). The ability to evaluate the suitability of retrieved information, and d). The ability to use effectively and appropriately the needed information. The advancement of the technology has changed the scope of the operationalization of ICT literacy (Erstad, 2006). Gilster (1998) provided a general explanation of ICT literacy as "Digital Literacy" and which explained it as "an ability to understand and to use information from a variety of digital sources" as well as Pool (1997) mentioned that "mastering ideas, not keystrokes". Digitally literate people are fast moving entities from one kind of medium to another kind and find out best fit knowledge through the information to become skilled person and represent knowledge to the audience in the easiest way to understand (Lankshear \& Knobel, 2008). Simultaneously, Lennon, Kirsch, Davier, Wagner \& Yamamoto (2003) mentioned "the interest, attitude, and ability of individuals to appropriately use digital technology and communication tools to access, manage, integrate, and evaluate information; construct new knowledge, and communicate with others in order to participate effectively in society". According to the above definitions DL may in beyond the ICT literacy and hence, the more dimensions of ICT implementations should be considered while studying the DL of an organization. Most of the researchers who concerned on ICT literacy or DL have studied the ICT usage of the organization (Esselaar, Stork, Ndiwalana \& Deen-Swarray, 2007).

Business Uncertainty: Uncertainty is a vital problem and it is first mentioned by Coase (1937) and it had been illuminated by Klein, Crawford \& Alchian (1978) with more specific idea as 'appropriable quasi rents' and it explained the uncertainty which make influences to vertical integration of firms. However, Williamson (1975) mentioned that uncertainty does not establish market failure, but firms may face difficulties by joining of uncertainty with human factors, such as bounded rationality and opportunism. According to Williamson (1985), there are two types of uncertainty behavioural and environmental. The dominant type is behavioural uncertainty and it is defined as "strategic nondisclosure, disguise or distortion of information" and is attributable to opportunism (Williamson, 1985). As the definition it is personal intervention and it occurs on the opportunistic behaviour of other transaction parties especially on specific assets which should be monitored more on transactions (David \& Han, 2004; Everaert, Sarens \& Rommel, 2010; Yousuf, 2017). Conversely, environmental uncertainty defined as the fact that the "environment is characterized by uncertainty with respect to technology, demand, local factor, supply conditions, inflation, and the like" (Williamson, 1985). Mainly, environmental uncertainty occurs due to the unpredictable or random actions or behaviour of nature or parties especially consumers. Williamson (1985) combined this nature with the bounded rationality and mentioned inability to obtain strategies to adapt the appropriate alternatives due to the lack of information and computational power.

Economic Performance: More researchers discussed the word performance in different aspects. Neely (2005) explained that: "doing today what will lead to measured value outcome tomorrow." The idea depends on the kind of benchmarking or standard to judge outcomes (Bourne, Franco \& Wilkes, 
INTERNATIONAL JOURNAL OF ACADEMIC RESEARCH IN BUSINESS AND SOCIAL SCIENCES Vol. 10, No. 5, May, 2020, E-ISSN: 2222-6990 @ 2020 HRMARS

2003; Khare, Saxsena \& Teewari, 2012; Morgan, 2004). Furthermore, performance is been mentioned as a series of business actions or procedures and it figured on the business as responsibility, accountability to the public and individuals (Cavalluzzo \& Ittner, 2004). Hence, the performance is not an objective concept as well as informative repetitive action which is depended on measures aims at the major objectives that opens the avenue from the previous actions to undecided position of the organization's future state (Lebas, 1995; Wholey, 1996). These measures of performance are the process of quantifying the actions which are being carried out by the organization and they can be subjective or objective as well as the use of both or combination of both for measuring performance can be determined by the objectives of the organization (Ilgen \& Favero, 1985).

According to Richard et al. (2009) the measurement of business performance uses some parameters such as plans, investments, and achievements to evaluate and estimate quantitatively and selection is more frustrated and controversial issue and hence, a deep agreement of the best measurements cannot be found. There are two aspects on selecting the measurement and some researchers concentrated on financial measures such as profitability, sales turnover, sales growth and return on investment, profitability and some recent studies mostly rely on the relevance of non-financial viewpoints such as personal satisfaction, personal growth, skill improvement, flexible lifestyle, business survival, customer satisfaction, customer retention, and career progress (Bititci et al., 2000; Buttner \& Moore, 1997; O’Regan \& Ghobadian, 2004; Perren, 2000; Simpson et al., 2004; Walker \& Brown, 2016).

It can be found that the economic performance has been defined on various perspectives and frequently and interchangeably uses with the financial performance (Zimmermann \& Foerstl, 2014). Hence, this research does not mainly consider the aggregate corporate performance measures and uses ground-level economic and financial measurements (Dara \& Douglas, 2016; Zhu \& Sarkis, 2004).

\section{Conceptual Framework and Hypotheses}

The major goal of the SEs is reach to the satisfactory level of EP. SEs fail to reach this level because of uncertainty (Priyanath, 2017; Priyanath \& Premarathne, 2014; Priyanath \& Premaratne, 2017a, 2017b). They need to make proper accurate decisions to avoid various inappropriate opportunistic influences which are raised on financial and environmental factors and conversely, it is the way of plastering the above uncertainty (Priyanath \& Premarathne, 2015). Furthermore, the human has the less rational ability and it again increases the inability of covering the uncertainty effects (Priyanto et al., 2014). The decision theories which can be used to make such optimum decisions are mainly depended on the availability of adequate, reliable and timely information (James, 2007; Kenneth \& Jane, 2013). Not like the past but now digital technologies provide adequate facilities to disseminate such information among transaction parties (Kenneth \& Jane, 2013). However, the problem is that the quantifiably measure the extent of literacy and use of these technologies for obtaining such valuable information to avoid the uncertainty barriers and finally facing the less opportunism to make the success of economic sustainability by minimizing the TC (Cordella, 2006, 2001; Pham, 2010).

The study developed two frameworks. The former is Framework 01 which explains the direct relationship among the dimensions of $\mathrm{DL}$, dimension of Business Uncertainty, and Economic Performance. The latter is Framework 02 which shows the overall relationship among variables; Business Uncertainty, and Economic Performance. Figure 01 shows that how different dimensions of $\mathrm{DL}$ affect the two dimensions of business uncertainty and thereby impact of both on Economic Performance of SEs in Sri Lanka. 
INTERNATIONAL JOURNAL OF ACADEMIC RESEARCH IN BUSINESS AND SOCIAL SCIENCES Vol. 10, No. 5, May, 2020, E-ISSN: 2222-6990 @ 2020 HRMARS

\section{Figure 01: Framework 1 - Direct Relationship among Dimensions}

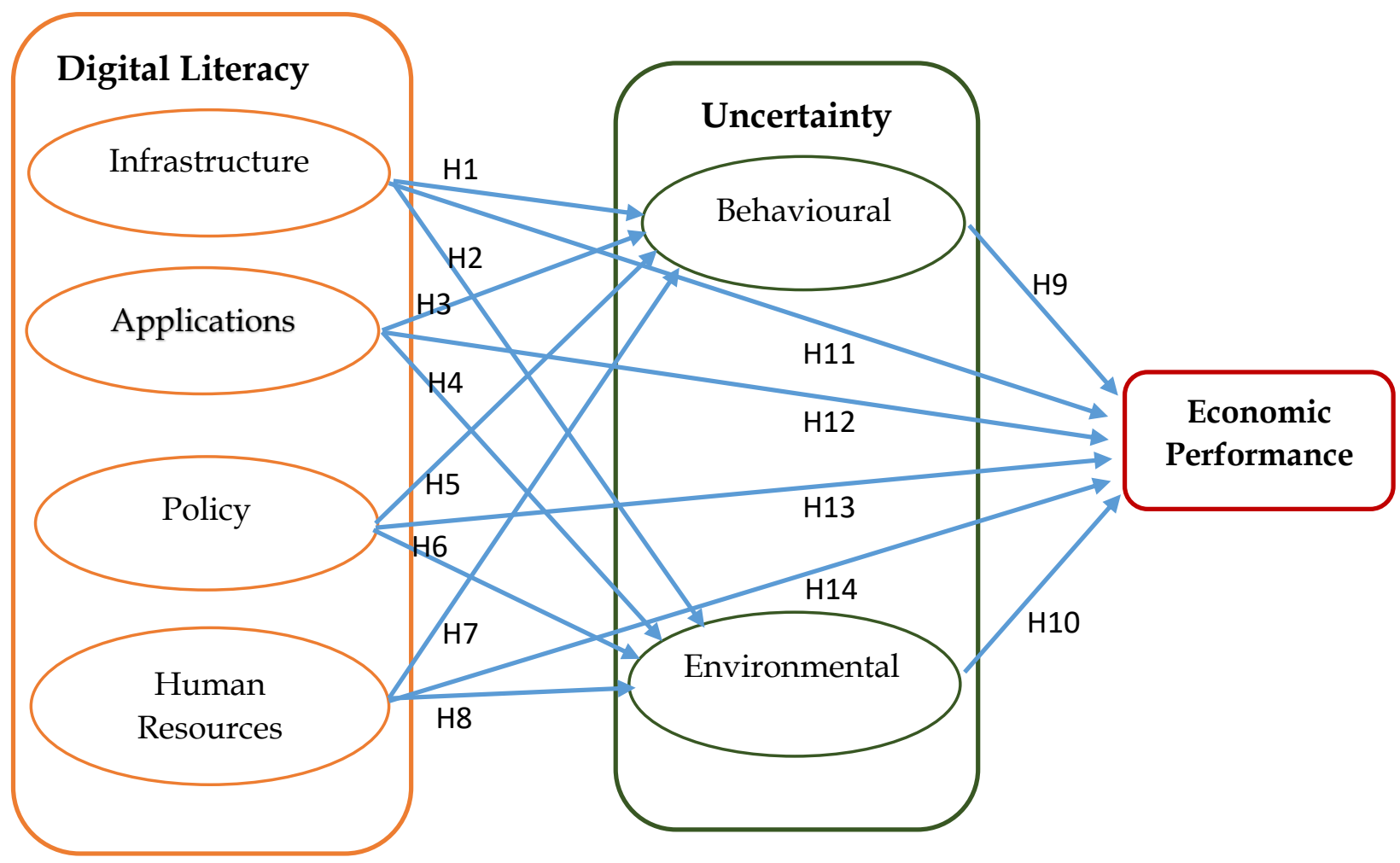

Digital Literacy and Economic Performance: Digital technologies make vital influences on business performances since it enables a massive network among the business, automation of business functions provides higher productivity, and smooth information flow makes proper decisions. (James, 2007; Kenneth \& Jane, 2013). Digital technologies make the collaborative environment and it helps to obtain innovations, research and development, decentralized decision-making and hence, it creates the visionary leadership for the organization which aims to the higher economic performance (Alam \& Noor, 2014; Esselaar et al., 2007; Giotopoulos et al., 2017; Harindranath et al., 2008; Kapurubandara \& Lawson, 2007). Consequently, some benefits associated with the usage of digital technology on SMEs illustrated that it can be used as a business tool to reduce costs, create stronger links with customers, innovate and facilitate market niche which prompts to a market transform from national to international (Apulu \& Latham, 2010; Kutlu, 2008). ICT adoption of the organization also a powerful strategic and tactical tool if it is applied properly which has a great impact in promoting and strengthening organizational competitiveness and thus, the economic performance (Apulu \& Latham, 2010; Asta \& Rimantas, 2014; Bayo-Moriones et al., 2013; Brynjolfsson \& Hitt, 2003; Buhalis, 2004; Kutlu, 2008; Liang et al., 2010). Therefore, the study hypothesizes that;

$\mathrm{H1}$ : Digital infrastructure positively relates to the economic performance of SEs.

$\mathrm{H} 2$ : Digital applications positively relates to the economic performance of SEs.

H3: Digital policy in the organization positively relates to the economic performance of SEs.

$\mathrm{H} 4$ : Human resource skills on digital literacy positively relates to the economic performance of SES

Digital Literacy and Uncertainty: Generally, high uncertainty depicts in the SEs on both environmental and behavioural since the absence of business experience and proper decisions as 
well as the absence of knowledge on business environment due to information gap (Ahmad \& Seet, 2009). Information sharing among the transaction parties provide more opportunities to SEs to increase the accuracy of decision making in the predictable market on uncertainty attributes such as volume of both purchase and selling directly pertaining to the environmental uncertainty. Conversely, transaction partners light up opportunism due to the unavailability or hiding up the information and it tends to the behavioural uncertainty (Ahmad \& Seet, 2009; John \& Weitz, 1988). If good communication arises among the business partners will reduce both environmental and behavioural uncertainty (Rindfleisch \& Heide, 1997). Although the empirical studies on the direct relationship among DL and business uncertainty do not available in the past literature the digital technologies and its capabilities provide various avenues to create such information network among the business partners and the market environment.

In the trend of globalization, digital technologies create vast knowledgebase and past experiences are been stored and used as business intelligence to minimize the coordination cost and especially the uncertainty (Cordella, 2006, 2001; Pham, 2010). ICT creates this digital world and the firm should identify the level of technological development which cater to address the uncertainty and Pham et al. (2013) identified that ICT infrastructure, applications, policy and human resources can be used to determine the level of maturity on digital technologies. Thus, the study predicts that:

$\mathrm{H} 5$ : Digital infrastructure negatively relates to the behavioural uncertainty of SES

H6: Digital infrastructure negatively relates to the environmental uncertainty of SES

H7: Digital applications negatively relates to the environmental uncertainty of SES

H8: Digital applications negatively relates to the behavioural uncertainty of SES

H9: Digital policy negatively relates to the behavioural uncertainty of SES

H10: Digital policy relates to the environmental uncertainty of SEs

H11: Human resource skills on digital literacy negatively relates to the behavioural uncertainty of SEs H12: Human resource skills on digital literacy negatively relates to the environmental uncertainty of SES

Business Uncertainty and Economic Performance: TCE expresses that if an organization face both behavioural and environmental uncertainty then it should implement a more reliable mechanism to avoid opportunism and furthermore, researchers have suggested that the uncertainty is a major determinant when a firm chooses governance mode (Balakrishnan \& Wernerfelt, 1986; Porter, 1980; Williamson, 1975). If the organization need to use high protection on uncertainty then the TC may go high and it may significantly affect the economic performance (Cordella, 2006, 2001). Priyanath \& Premarathna (2014), (2017a), (2017b), as well as Priyanath \& Buthsala (2017), confirmed that the SEs of Sri Lanka faced high transaction cost which makes barriers on the growth of SMEs. Therefore, uncertainty increases the TC and TC decreases the economic performance of an organization. In order to test this theoretical relationship, the study predicts the following hypothesis;

H13: Behavioural uncertainty negatively relates to the economic performance of SEs

$\mathrm{H} 14$ : Environmental uncertainty negatively relates to the economic performance of SES

\section{Framework 02 - Overall Relationship among Variable}

Figure 02 shows that how DL conceptually affects the business uncertainty and economic performance of SEs in Sri Lanka. It is expected that the DL has a positive relationship between economic performance and the negative relationship between business uncertainty and also 
INTERNATIONAL JOURNAL OF ACADEMIC RESEARCH IN BUSINESS AND SOCIAL SCIENCES Vol. 10, No. 5, May, 2020, E-ISSN: 2222-6990 @ 2020 HRMARS

business uncertainty has a negative relationship between economic performance. Furthermore, the business uncertainty has a mediate relationship between $\mathrm{DL}$ and economic performance.

Figure 02: Overall effect of DL on Business Uncertainty and Economic Performance

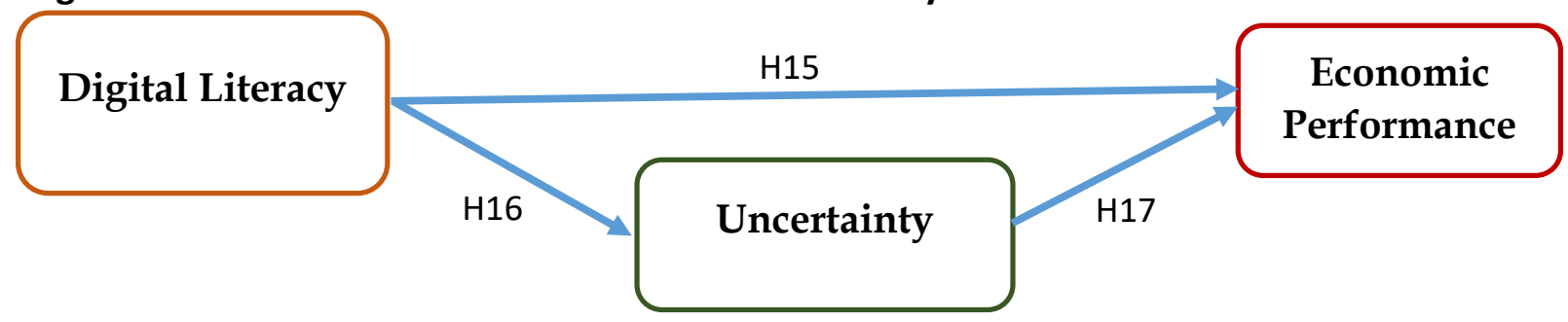

DL is been using to reduce the imperfection of the economic systems which has made solutions to avoid uncertain settings and inefficiencies in the organization of transactions in the complex market environment. Thus, the DL reduces the business uncertainty. However, TC also arise due to interdependencies among the various factors contributing to their growth (Cordella, 2006, 2001). Especially on coordination cost on uncertain environment and thus, the transaction cost (Cordella \& Simon, 1997). Accordingly, they suggest to use digital technology for reducing information flux, coordination needs inside the organization, and organizational structure devoted to support coordinative activities. Following that strategy, it is possible to reduce internal coordination cost, and thus transaction cost. It is also possible to avoid the disintegration of the organization as a consequence of information overload and structural growth. Organizations attempt on more outsourcing and mitigate the transaction cost since the use of digital technology (Nooteboom, 1992). Amaradiwakara \& Gunatilake (2016) mentioned that poor business performance of Sri Lankan Small and Medium Enterprises due to financial inefficiency, lack of access to new knowledge and technological literacy and education. Therefore, the study predicts the following hypotheses;

H15: Digital literacy positively relates to the economic performance of SES

H16: Digital literacy negatively relates to the business uncertainty of SEs

H17: Business uncertainty negatively relates to the economic performance of SEs.

H18: Business uncertainty has a mediating role in the relationship between digital literacy and economic performance of SEs

\section{Methodology}

The deductive approach has been utilized and the method was quantitative in order to study the research problem. The data collection was done by using the survey method. Since the SEs mostly participate in transactions on buying input and selling output in manufacturing organizations the research study selected only manufacturing SEs for the study. The unit of analysis was the owner of SEs who directly start, manage and run the business. The definition given by the Department of Census and Statistics (DCS) of Sri Lanka SEs are considered as established organizations with $5-24$ persons and this definition has been employed for selecting the study population and as mentioned in the DCS of Sri Lanka the population value was 14,185 manufacturing SEs. The sample frame $(14,185$ of SEs), 110 of SEs were selected employing the minimum sample size determination formula for the Partial Least Square - Structural Equation Modelling (PLS-SEM) after conducting the pilot survey and analysis of 40 SEs (Kock \& Hadaya, 2018; Ranatunga, Priyanath \& Meegama, 2020). The sample 
populated according to the percentage share of the SEs which are located in each district and determine the number of SEs to represent all the districts in Sri Lanka. Then, SEs of each districts were listed out according to the ISIC category and the sample were selected using stratified sampling method to represent all the manufacturing industrial divisions.

The questionnaire has been developed by using two-step procedure as at the starting initially identified a pool of items of each dimension by reviewing empirical literature and carefully nominated items which are more helpful to measure the dimensions of the constructs. Therefore, the items of the questionnaire were systematically designed according to the literature published in cited journals. The 7-point Likert scales (1 - Strongly disagree; 2 - Disagree; 3 - Somewhat disagree; 4 Neither agree nor disagree; 5 - Somewhat agree; 6 - Agree; 7 - Strongly agree) utilised to obtain the ranked answers given by each respondent according to their agreement for the question statement. In order to protect the validity and reliability of the study the questionnaire has been pre tested by using a pilot survey before the main survey and it is verified whether the questions are understood; whether the instructions are clear; whether the order of the questions is appropriate and the questions are useful etc. The owner is the 'entrepreneur' and the manager in the majority of SEs in Sri Lanka and thus, face to face interviews were conducted with them to collect data.

The hypothetical relationships were measured by using the PLS-SEM which is a statistical analysis used to analyse the relationship between multiple independent and dependent variables as well as can evaluate more than one construct at the same time. The reliability and validity tests and the efficiency of the model has been examined by multi-collinearity issues, R2, effect size ( $f 2$ ) and predictive relevance (Q2). The SmartPLS (version 3) software was used to analyse data.

Digital Literacy: DL is a broader concept which is been achieved by the long-term capacity of using ICT. Hence, It is been measured using four variables such as implemented ICT infrastructure, used ICT applications, organization's ICT policy, and ICT skilled human resources (Giotopoulos et al., 2017; Mithas et al., 2012; Pham, 2010; Pham et al., 2013). According to Pham (2010) and Pham et al. (2013) 11 items used to measure the infrastructure and 14 items used to measure applications while 10 items were being used for measuring the policy and 12 items to measure skilled human resources.

Business Uncertainty: Business Uncertainty has been divided into two variables and the environmental uncertainty directly depends on the outside of the organization which can be measured on Technology, demand and supply according to the study context. John \& Weitz (1988) and Noorderhaven (1996) measured the demand uncertainty by using four items and this study also used as the same and according to Chen \& Chen (2003), another four items have used to measure the supply uncertainty whereas Poppo \& Zenger (1998) measured technological uncertainty using two items on skills and application changes. Conversely, behavioural uncertainty has been measured by using two items such as evaluating the performance of transaction parties and evaluate the risk of opportunism of the transaction parties (Chen \& Chen, 2003; Kamyabi \& Devi, 2011; Rindfleisch \& Heide, 1997; Shin, 2003).

Economic Performance: Undoubtedly digital technologies and capabilities have a powerful impact on the economic performance of an organization and could be characterized by vast technological progress and productivity. More researchers empirically used profitability measures as the main 
indicators of company performance. However, according to Asta \& Rimantas (2014) profitability measures give an inadequate result on the performance and can cause misleading information. Liang et al. (2010) and Santos \& Brito (2012) identified that two types of performance such as financial performance and strategic (operational) performance. The financial performance measured as profitability, growth, market value and conversely, strategic or operational performance indicated by customer satisfaction, employee's satisfaction, environmental performance and social performance. This study also used both financial and strategic or operational performance and according to Santos \& Brito (2012) and Asta \& Rimantas (2014) within the financial performance, profitability operationalizes by five items, growth operationalize by five items and market value operationalize by using another five items. Consequently, within the strategic or operational performance, customer satisfaction operationalizes by six items, employee's satisfaction operationalizes by five items, environmental performance operationalizes by six items and social performance operationalize by another four items.

\section{Results and Discussions}

According to (Hair et al., 2012) "All variables used in multivariate techniques must be assumed to have some degree of measurement error". Any researcher must attempt to minimize this measurement error as possible as. According to Hair et al. (2012) the degree of the measurement error existing in any kind of measure can be assessed by using two important characteristics of such measure called validity and reliability. The validity of a particular measure denotes what a degree of that measure accurately represents what it is designed to use (Hair et al., 2012; Robson, 2002; Thatcher, 2010).

The study evaluates the results in two step procedure. Step one is model 01, step two is model 02. Initially, the study evaluated the validity and reliability of the measurement model or outer model of model 1 which consists of reflective indicators. The reliability of the reflective indicator variables are been evaluated by using two factors in the PLS-SEM such as 1) indicator reliability and 2) internal consistency reliability, as well as the validity of the reflective indicator variables, are been evaluated by using another two factors as 1) convergent validity and 2) discriminant validity (Hair et al., 2014). Based on PLS-SEM measurement of outer model of model 01, first, the study evaluated 06 of firstorder endogenous latent variables. The appendix I shows standardised factor loadings which were above than the minimum threshold criterion 0.7 confirming the indicator reliability of first-order reflective constructs and factor loading also statistically significant at 0.05 level. Further, it shows that the Cronbach's $\alpha$ was higher than the required value of 0.7 and the composite reliability was higher than the recommended 0.7 value as well as it depicts and confirmed the convergent validity of the first order constructs. According to Fornell \& Larcker (1981), the square root of AVE in each latent variable can be used to establish discriminant validity. These values should be larger than other correlation values among the latent variables. As mentioned in the appendix II all the inter-construct correlation values are lower than the square root of the AVE and satisfied the criterion of the discriminant validity of first-order constructs.

The latent variable scores of the first order constructs are been used for develop the second-order constructs. Seven endogenous latent variables such as economic performance (EP), DL Applications (DLAppli), DL Human Resources (DLHR), DL Infrastructure (DLInfra), DL Policy (DLPolicy), Behavioural Uncertainty (UnBehe) and Environmental Uncertainty (UnEnvi) have been utilized at the second order level in the hierarchical model and evaluated them. Appendix III indicates that all the path 
coefficients are higher than the required threshold value 0.7 . The significance of each path coefficient should be estimated and the bootstrapping procedure was conducted and examined the t-statistics. According to Appendix III all the t-statistics are significant at the 0.05 significance level. Furthermore, Cronbach's $\alpha$ and composite reliability have been obtained and both values are higher than the recommended value of 0.7 on all the second order constructs and it depicts that all the second order constructs were created by using the reliable methods. These results endorsed the convergent validity of the second-order construct used in the model. Appendix IV utilized to indicate the discriminate validity of the second-order constructs and it shows that all the square-root of the AVE are higher than the inter-construct correlation values and it satisfied the criterion of the discriminant validity of the second-order constructs.

Hair et al. (2014) has guided and recommended five steps to assess the structural model. The initial step is assessing the collinearity issues. According to appendix V, VIF values ranging from 1.41 to 3.22 and hence the analysis does not depict any collinearity issues since VIF values are lower than the threshold 5. As well as the tolerance levels range from 0.311 to 0.709 which exceeded the threshold value 0.2 . It indicates that the structural model does not contain any multicollinearity between the independent constructs and the dependent constructs.

The significance of the path coefficients in the structural model of model 01 has been estimated to decide the effect of DL on the business uncertainty and the economic performance. PLS bootstrap process used for evaluating the path regression coefficient $(\beta)$ with the $t$-statistics. Path coefficient should be larger than 0.1 in order to demonstrates its significance and the t-value is 1.65 for a significance level of $90 \%, 1.96$ for a significance level of $95 \%$ and 2.58 for a significance level of $99 \%$ in the two-tailed t-test. Table 01 demonstrate the analysis result and it mentioned that the 14 hypothetical relationships have been considered in the structural model of model 01 and 9 (64.2\%) relationships were significant.

Table 01: Path Coefficient and Significance

\begin{tabular}{|c|l|c|c|c|}
\hline Hypotheses & \multicolumn{1}{|c|}{ Relationship } & Beta (Path) & T Value & Decision \\
\hline H1 & DLInfra -> UnBehe & -0.150 & 1.218 & Not accepted \\
\hline H2 & DLInfra -> UnEnvi & -0.073 & 0.708 & Not accepted \\
\hline H3 & DLAppli -> UnBehe & $-\mathbf{0 . 2 0 7 * *}$ & 1.960 & Accepted \\
\hline H4 & DLAppli -> UnEnvi & $-\mathbf{0 . 1 6 8 ^ { * }}$ & $\mathbf{1 . 9 2 6}$ & Accepted \\
\hline H5 & DLPolicy -> UnBehe & 0.0579 & 0.605 & Not accepted \\
\hline H6 & DLPolicy -> UnEnvi & -0.0737 & 0.952 & Not accepted \\
\hline H7 & DLHR -> UnBehe & $-\mathbf{0 . 3 2 9 * *}$ & $\mathbf{2 . 2 5 0}$ & Accepted \\
\hline H8 & DLHR - UnEnvi & $-\mathbf{0 . 5 0 4 * * *}$ & $\mathbf{5 . 3 1 5}$ & Accepted \\
\hline H9 & UnBehe -> EP & $-\mathbf{0 . 2 3 3 ^ { * * * }}$ & $\mathbf{3 . 2 9 2}$ & Accepted \\
\hline H10 & UnEnvi -> EP & $-\mathbf{0 . 1 9 2 * *}$ & $\mathbf{1 . 9 8 7}$ & Accepted \\
\hline H11 & DLInfra -> EP & $\mathbf{0 . 2 0 4 * *}$ & $\mathbf{2 . 2 5 8}$ & Accepted \\
\hline H12 & DLAppli -> EP & $\mathbf{0 . 1 7 3 * *}$ & $\mathbf{2 . 0 6 8}$ & Accepted \\
\hline H13 & DLPolicy -> EP & $\mathbf{0 . 1 4 7 * *}$ & $\mathbf{2 . 1 2 4}$ & Accepted \\
\hline H14 & DLHR -> EP & 0.158 & 1.484 & Not accepted \\
\hline
\end{tabular}

*P $>0.1,{ }^{* *} \mathrm{P}>0.05, * * * \mathrm{P}>0.01$

Source: Survey Data, 2020. 
It has been examined the correlation between dependent and independent variables as the next step. According to the required thresholds the model having $\mathrm{R}^{2}$ as $0.67,0.33$, and 0.19 are considered as substantial, moderate, and weak respectively. According to the result, the relationship between DL and economic performance of SEs contains 0.74 (substantial), the relationship DL and behavioural uncertainty contains 0.33 (moderate) and finally, the relationship DL and environmental uncertainty has 0.51 (moderate) correlation. The effect size of the predictive variables $f^{2}$ as well as $Q^{2}$ of the model variable have been evaluated and the large effect size depicted by the calculations. Thus the goodness of fit of the model is suitable for the predictions. Appendix VI presents the result.

Pham et al. (2013) identified that ICT infrastructure, applications, policy and human resources can be used to determine the level of maturity on digital technologies. These technologies generate massive network among the business partners and it affect to make good communication among them. However, the direct relationships among the above characteristics of the DL and the business uncertainty have not been experimented by the previous studies and this study attempt to reveal it. As predicted by this study the negative relationships are obtained in the result among all the major characteristics of the DL and the business uncertainty. It means that if the DL increases in the SEs then the business uncertainty can be reduced. Therefore, the predictions of $H 1, H 2, H 3, H 4, H 6, H 7$, and $\mathrm{H} 8$, can be accepted except $\mathrm{H} 5$. However, according to the findings digital technology applications and the human resource skills are the most significant and if the digital technology applications increase it will reduce both behavioural uncertainty and environmental uncertainty $(\beta=$ -0.206785 or 20 percent and $t$-value $=1.96$ and $\beta=-0.167743$ or 16 percent and $t$-value $=1.92$ ) as well as the human resources in the digital technology make more impact ( $\beta=-0.329317$ or 32 percent and $\mathrm{t}$-value $=2.25$ and $\beta=-0.503618$ or 50 percent and $\mathrm{t}$-value $=5.31$ ) on handling the business uncertainty. Although the digital infrastructure and used digital policies shows negative impact the significance of these relationships is very low in especially on environmental uncertainty. Because most of the SEs are typically using minimum infrastructure facilities such as fixed telephone, mobile phones and computers and related equipment and do not use computer networking and the internet related technologies which may mostly help to make more inter network among business environment to minimize the information gap. Further, the study revealed that the Sri Lankan SES still do not concern and implement proper digital policies to handle their technological aspects.

Priyanath \& Premarathne (2014) and Priyanath \& Premaratne (2017a, 2017b), as well as Priyanath \& Buthsala (2017), explained that the SEs of Sri Lanka faced high transaction cost which makes barriers on the growth of SEs. According to their studies, the uncertainty increases the TC and TC decreases the economic performance of the Sri Lankan SEs. This study also proved these previous findings and the negative impacts on both behavioural and environmental uncertainty on the economic performance $(\beta=-0.232837$ or 23 percent and $t$-value $=3.29$ and $\beta=--0.192302$ or 19 percent and t-value $=1.987254$ ) of the SEs depicted in the table 02 . Therefore, $\mathrm{H} 9$ and $\mathrm{H} 10$ can be accepted.

\section{Step 02: Evaluation of Model 2}

First, the reliability of the third-order constructs is been evaluated as indicator reliability and internal consistency reliability, as well as the validity of the constructs, are been evaluated by using another two factors as convergent validity and discriminant validity. According to Appendix VII all the factor loading values are above 0.7 and those are statistically significant at 0.05 level as well as the Cronbach's $\alpha$ is higher than the 0.7 value. Thus the reliability of third-order construct is in satisfactory 
INTERNATIONAL JOURNAL OF ACADEMIC RESEARCH IN BUSINESS AND SOCIAL SCIENCES Vol. 10, No. 5, May, 2020, E-ISSN: 2222-6990 @ 2020 HRMARS

level and also Appendix VII shows that the AVE values and their square roots of each variable indicated the convergent and discriminant validity too in a satisfactory level.

Table 02: Path Coefficients and Significance levels (T-Values)

\begin{tabular}{|l|c|c|c|}
\hline \multicolumn{1}{|c|}{ Hypotheses } & Path & T Value & Decision \\
\hline DL -> EP & 0.539 & 7.150 & Accepted \\
\hline Digital Literacy -> Uncertainty & -0.727 & 15.693 & Accepted \\
\hline Uncertainty -> EP & -0.373 & 4.942 & Accepted \\
\hline
\end{tabular}

Source: Survey Data, 2020.

Digital technologies provide more facilities on economic performance since it enables massive network among the business, automation of business functions provides higher productivity, and smooth information flow makes proper decisions and it is empirically proved by Alam \& Noor (2014), Esselaar et al. (2007), Giotopoulos et al. (2017), Harindranath et al. (2008), Kapurubandara \& Lawson (2007). However, most of these studies are based on literature and did not provide adequate empirical examination and proof. Although the relationships which this study is directly going to find did not empirically examined previously, the same ideas have been revealed in totally by this study except the technological human resource skills. According to the table 01, DL infrastructure, applications and policies have positive impact on economic performance $(\beta=0.203565$ or 20 percent and $t$-value $=2.26$ and $\beta=0.172947$ or 17 percent and $t$-value $=2.07$ and $\beta=0.147026$ or 14 percent and t-value $=2.12$ respectively) and hence, $\mathrm{H} 11, \mathrm{H} 12$, and $\mathrm{H} 13$ can be accepted. However, although the human resource on the technology may positively make influence to the economic performance of SEs (15 percent) it does not significantly affect and therefore, the study rejected the H14.

As mentioned in the above the total positive effect of digital infrastructure, applications, policies and human resources on the economic performance has been tested under the $\mathrm{H} 15$ and it is been accepted because it has $0.538702 \beta$ value (53 percent) under the t-statistics 7.14 significance level as mentioned in the table 02. It means that the total effect of DL makes 53 percent of influence on the economic performance of the SEs in Sri Lanka. As well as the table 03 shows that the total effect of $D L$ on uncertainty makes a negative effect with $-0.727008 \beta$ value ( 72 percent) under t-statistics 15.69 and therefore, the $\mathrm{H} 16$ hypothesis has strongly been accepted. The total negative effect of behavioural and environmental uncertainty also tested under the $\mathrm{H} 17$ and according to table 03 the 37 percent negative effect ( $\beta$ value -0.373194 ) under t-statistics 4.94 discovered and thus, it is been accepted.

This study concerned the mediate effect of business uncertainty on the relationship between DL and the SE economic performance under the $\mathrm{H} 18$ and this kind of relationship has not been empirically studied in the literature. Table 03 shows the analysis of the mediate effect of uncertainty and it depicts complementary mediate effect (VAE value is 0.335 ) between DL and Economic performance of SEs in Sri Lanka and the H18 is been accepted. 
INTERNATIONAL JOURNAL OF ACADEMIC RESEARCH IN BUSINESS AND SOCIAL SCIENCES Vol. 10, No. 5, May, 2020, E-ISSN: 2222-6990 @ 2020 HRMARS

Table 03: Mediate effect of uncertainty on DL and Economic Performance of SEs

\begin{tabular}{|c|c|c|c|c|c|c|c|c|}
\hline \multirow[b]{2}{*}{ Path } & \multicolumn{2}{|c|}{$\begin{array}{c}\text { Direct effect } \\
\text { model }\end{array}$} & \multirow{2}{*}{$\begin{array}{c}\begin{array}{c}\text { Indire } \\
\text { ct }\end{array} \\
\text { effect }^{c}\end{array}$} & \multirow{2}{*}{$\begin{array}{c}S_{e^{d}} \\
(S D)\end{array}$} & \multirow{2}{*}{$\begin{array}{c}\text { t-stat } \\
(a x b) / \\
S_{e}\end{array}$} & \multirow{2}{*}{$\begin{array}{c}\begin{array}{c}\text { Total } \\
\text { effect }^{f}\end{array} \\
(a \times b)+c\end{array}$} & \multirow{2}{*}{$\begin{array}{c}\text { VAF } \\
\text { axb/ } \\
(a x b)+ \\
c\end{array}$} & \multirow{2}{*}{$\begin{array}{l}\text { Type of the } \\
\text { mediation }\end{array}$} \\
\hline & $\boldsymbol{\beta}^{\mathrm{a}}$ & t-stat & & & & & & \\
\hline $\begin{array}{l}\mathrm{DL} \longrightarrow \mathrm{EP} \\
(\mathrm{c})\end{array}$ & $\begin{array}{c}0.53 \\
9\end{array}$ & 7.149 & 0.271 & 0.063 & 4.343 & 0.81 & 0.335 & Complementary \\
\hline $\begin{array}{l}\mathrm{DL} \longrightarrow \\
\text { Unce (a) }\end{array}$ & $\begin{array}{c}- \\
0.72 \\
7\end{array}$ & 15.69 & & & & & & \\
\hline $\begin{array}{l}\text { Unce } \longrightarrow \\
\mathrm{EP}(\mathrm{b})\end{array}$ & $\begin{array}{c}- \\
0.37 \\
3\end{array}$ & 4.942 & & & & & & \\
\hline
\end{tabular}

Source: Survey Data, 2020.

\section{Conclusions}

The study mainly argued that the DL boosts economic development because the DL reduces the business uncertainty which directly reduce the transaction cost of SEs and thereby increase the economic performance. The study has developed a conceptual model based on the above relationship and working hypotheses have been developed to test it empirically in SEs in Sri Lanka. The results discovered that the different categories of DL implemented in the organization totally make significant positive impact on the economic performance as well as negatively influenced the business uncertainty. The study recognized that the DL makes an overall impact to minimize the factors of business uncertainty of the SEs and it directly affects to increase the economic performance. Meanwhile, the study revealed that business uncertainty plays a dominant role in the relationship between $\mathrm{DL}$ and economic performance. However, according to the individual characteristics of the DL some dimensions are not significantly affected with the business uncertainty. Mostly, digital applications make more influence on business uncertainty than other dimensions. Because internet-based applications used by these SEs through mobile phones other than using the sophisticated digital infrastructure with computers and related computer network facilities. Conversely, it is a cheaper method to obtain market information such as information on the buyer, supplier as well as input materials and hence the uncertainty may reduce. Further, this trend does not need to implement more rules and regulations under handling information since the personalized information controlling with computer databases are not required. Therefore, these SEs do not concern on either infrastructure or policy implementation on digital technology. Sri Lankan government has implemented more facilities as well as education to enhance the knowledge on DL and hence the citizen generally rich on handling digital technology especially mobile equipment. The results show this phenomenon also because the DL human resources make more influence to the business uncertainty.

The study makes significant contribution to the literature by developing a combined model using theoretical base of DL, business uncertainty and economic performance to understand how DL affects the business uncertainty and economic performance in the context of SEs. This combination of theoretical aspects has not been empirically studied by previous researchers measuring the economic 
performance especially, and thus, the study makes valuable insight to understand the practical efficacy of theories in the context of SEs in Sri Lankan. The DL quantified by covering typically available technologies that have not been considered extensively in the past researchers and also the economic performance. Therefore, it is a vital contribution to the future researchers on quantifying this kind of theoretical combinations especially, in the environment of SEs.

The study recommends policymakers to enhance the existing technologies especially on mobile applications other than the sophisticated computer-related applications to cater to the SEs in Sri Lanka for increase the usage and information handling. The connection through the mobile devices cheaper and hence, the SEs can reach the cost other than implementing the computer related technologies and even all the less educated people also can utilize the technology. Government agencies, private sector organizations especially on telecommunication sector can maintain services like mobile applications, mobile data services to enhance the connections between SEs and market to avoid the business uncertainty and it will help to make SEs network with more reliable and guaranteed connections not only in the local market but also the international market environment. The empirical evidences of the relationship between $\mathrm{DL}$ through the above dimensions with uncertainty has not been in the past literature especially, regarding the SEs and the attempt of this study is a good starting point. However, further researchers should enhance these dimensions as suitable to the technological face of the country. The generalization of the findings is restricted to a small sample. Further researchers are suggested to carry out an extensive study with a larger sample. The generalization of the research findings will be limited to Sri Lanka. However, the findings may not be applicable to the other countries because the $\mathrm{DL}$, business uncertainty and economic performances become change with the different cultural backgrounds and socio-economic conditions. Future researches are suggested to carry out studies in another region of the world with different cultural and socio-economic background to know how empirical evidences differ from Sri Lanka.

\section{References}

Abdullah, M. A., \& Beal, T. (2003). The strategic contributions of small and medium enterprises to the economics of Japan and Malysia: Some comparative lessons for Malysian SMEs. The Seventh International Conference on Global Business and Economic Development, 1337-1354.

Abor, J., \& Quartey, A. (2010). Issues in SME Development in Ghana and South Africa. International Research Journal of Finance and Economics, 39(6), 215-228.

Agwu, M. O., \& Emeti, C. I. (2014). Issues, challenges and prospects of small and medium scale enterprises (SMEs) in Port-Harcourt city in Nigeria. European Journal of Sustainable Development, 3(1), 101-114.

Ahmad, N. H., \& Seet, P. S. (2009). Dissecting behaviours associated with business failure: A qualitative study of SME owners in Malaysia and Australia. Asian Social Science, 5(9), 98-104.

Alam, S. S., \& Noor, M. K. (2014). ICT adoption in small and medium enterprises: An empirical evidence of service sectors in Malaysia. International Journal of Business and Management, 2(4), 112-125.

Amaradiwakara, A. U., \& Gunatilake, M. M. (2016). Factors affecting growth of small and medium enterprises in Sri Lanka. Journal of Business \& Economic Policy, 3(4), 62-71. 
INTERNATIONAL JOURNAL OF ACADEMIC RESEARCH IN BUSINESS AND SOCIAL SCIENCES

Vol. 10, No. 5, May, 2020, E-ISSN: 2222-6990 @ 2020 HRMARS

American Library Association (ALA). (2006). Presidential committee on information literacy: Final report [Text]. Association of College \& Research Libraries (ACRL). http://www.ala.org/acrl/publications/whitepapers/presidential

Apulu, I., \& Latham, A. (2010). Benefits of information and communication technology in small and medium sized enterprises: A case study of a Nigerian SME. 7.

Asta, T., \& Rimantas, G. (2014). ICT impact on SMEs performance. Contemporary issues in business management and education. Social and Behavioral Sciences, 2013, Procedia-110, 1218-1225.

Balakrishnan, S., \& Wernerfelt, B. (1986). Technical change, competition and vertical integration. Strategic Management Journal, 7, 347-359.

Bayo-Moriones, A., Billón, M., \& Lera-López, F. (2013). Perceived performance effects of ICT in manufacturing SMEs. Industrial Management \& Data Systems, 113(1), 117-135. https://doi.org/10.1108/02635571311289700

Bititci, U. S., Turner, Ut., \& Begemann, C. (2000). Dynamics of performance measurement systems. International Journal of Operations \& Production Management, 20(6), 692-704. https://doi.org/10.1108/01443570010321676

Bourne, M., Franco, M., \& Wilkes, J. (2003). Corporate performance management. Measuring Business Excellence, 7(3), 15-21.

Brynjolfsson, E., \& Hitt, L. (2003). Computing productivity: Firm-level evidence. The Review of Economics and Statistics, 85(4), 793-808.

Buhalis, D. (2004). eAirlines: Strategic and tactical use of ICTs in the airline industry. Information \& Management, 41(7), 805-825.

Buttner, E. H., \& Moore, D. P. (1997). Women's organizational exodus to entrepreneurship: Selfreported motivations and correlates with success. Journal of Small Business Management, 35(1), 34.

Carmel, E., \& Nicholson, B. (2005). Small firms and offshore software outsourcing: High transaction costs and their mitigation. Journal of Global Information Management, 13(3), 33-54,.

Cavalluzzo, K. S., \& Ittner, C. D. (2004). Implementing performance measurement innovations: Evidence from government. Accounting, Organizations and Society, 29(3-4), 243-267. https://doi.org/10.1016/S0361-3682(03)00013-8

Chen, H., \& Chen, T.-J. (2003). Governance structures in strategic alliances: Transaction cost versus resource-based perspective. Journal of World Business, 38(1), 1-14. https://doi.org/10.1016/S1090-9516(02)00105-0

Coase, R. H. (1937). The nature of the firm. Economica, 4, 386-405.

Cordella, A. (2006). Transaction costs and information systems: Does IT add up? Journal of Information Technology, 21(3), 195-202(8).

Cordella, A. (2001). Does information technology always lead to lower transaction costs? Global CoOperation in the New Millennium, The 9th European Conference on Information Systems, Bled, Slovenia, 854-864.

Cordella, A., \& Simon, K. (1997). The impact of information technology on transaction and coordination cost. K. Braa and E. Monteiro (Eds.) Social Informatics: Proceedings of IRIS 20, Department of Informatics, University of OSLO.

Dara, G. S., \& Douglas, N. H. (2016). Cloud computing and its impact on economic and environmental performance: A transaction cost economics perspective. Decision Support Systems, 86, 7382. https://doi.org/10.1016/j.dss.2016.03.009 
INTERNATIONAL JOURNAL OF ACADEMIC RESEARCH IN BUSINESS AND SOCIAL SCIENCES

Vol. 10, No. 5, May, 2020, E-ISSN: 2222-6990 @ 2020 HRMARS

David, R. J., \& Han, S. K. (2004). A systematic assessment of the empirical support for transaction cost economics. Strategic Management Journal, 25(1), 39-58. https://doi.org/10.1002/smj.359

Erstad, O. (2006). A new direction? Education and Information Technologies, 11(3), 415-429. https://doi.org/10.1007/s10639-006-9008-2

Esselaar, S., Stork, C., Ndiwalana, A., \& Deen-Swarray, M. (2007). ICT usage and its impact on profitability of SMEs in 13 African countries. Information Technologies and International Development, 4(1), 14.

Everaert, P., Sarens, G., \& Rommel, J. (2010). Using Transaction Cost Economics to explain outsourcing of accounting. Small Business Economics, 35(1), 93-112. https://doi.org/10.1007/s11187-008-9149-3

Fornell, C., \& Larcker, D. F. (1981). Evaluating structural equation models with unobservable variables and measurement error. Journal of Marketing Research, 18(1), 39-50. JSTOR. https://doi.org/10.2307/3151312

Gbandi, E. C., \& Amissah, G. (2014). Financing options for small and medium enterprises (SMEs) in Nigeria. European Scientific Journal, ESJ, 10(1), 327-340.

Gilster, P. (1998). Digital literacy (1st edition). Wiley.

Giotopoulos, I., Kontolaimou, A., Korra, E., \& Tsakanikas, A. (2017). What drives ICT adoption by SMEs? Evidence from a large-scale survey in Greece. Journal of Business Research, 81, 60-69. https://doi.org/10.1016/j.jbusres.2017.08.007

Hair, J. F., Hult, G. T. M., Ringle, C. M., \& Sarstedt, M. (2014). A primer on partial Least Squares Structural Equation Modeling (PLS-SEM). Thousand Oaks, California: SAGE Publications.

Hair, J. F., Sarstedt, M., Ringle, C. M., \& Mena, J. A. (2012). An assessment of the use of partial least squares structural equation modelling in marketing research. Journal of the Academy of Marketing Science, 40(3), 414-433. https://doi.org/10.1007/s11747-011-0261-6

Harindranath, G., Dyerson, R., \& Barnes, D. (2008). ICT in small firms: Factors affecting the adoption and use of ICT in Southeast England SMEs. 16th European Conference on Information Systems, ECIS, Galway, Ireland.

Hashim, M. K. (2000). SMEs in Malaysia: Past, present and future. Malaysian Management Review, 35(1), 22-30.

Henderson, J., \& Weiler, S. (2009). Entrepreneurs and Job growth: Probing the boundaries of time and space: Economic Development Quarterly, 24(1), 23-32. https://doi.org/10.1177/0891242409350917

Ilgen, D. R., \& Favero, J. L. (1985). Limits in generalization from psychological research to performance appraisal processes. Academy of Management Review, 10(2), 311-321. https://doi.org/10.5465/amr.1985.4278227

James, A. O. (2007). Management Information Systems (7th ed.). McGraw-Hill.

Jamil, C. M., \& Mohamed, R. (2011). Performance measurement system (PMS) in small medium enterprises (SMES): A practical modified framework. World Journal of Social Sciences, 1(3), 200-212.

John, G., \& Weitz, B. A. (1988). Forward integration into distribution: An empirical test of transaction cost analysis. Journal of Law, Economics, \& Organization, 4(2), 337-355.

Kamyabi, Y., \& Devi, S. (2011). The impact of accounting outsourcing on Iranian SME performance: Transaction cost economics and resource-based perspectives. World Applied Sciences Journal, 15(2), 244-252. 
INTERNATIONAL JOURNAL OF ACADEMIC RESEARCH IN BUSINESS AND SOCIAL SCIENCES

Vol. 10, No. 5, May, 2020, E-ISSN: 2222-6990 @ 2020 HRMARS

Kapurubandara, M., \& Lawson, R. (2007). SMEs in developing countries need support to address the challenges of adopting e-commerce technologies. BLED 2007 Proceedings, 24, 16.

Kayanula, D., \& Quartey, P. (2000). The policy environment for promoting small and medium-sized enterprises in Ghana and Malawi. Finance and Development Research Programme, Working Paper Series, Paper No 15, IDPM, University of Manchester, 29.

Kenneth, C. L., \& Jane, P. L. (2013). Management Information Systems: Managing the Digital Firm (12th ed.). Prentice Hall.

Khare, A., Saxsena, A., \& Teewari, P. (2012). Supply chain performance measures for gaining competitive advantage: A review. Journal of Management and Strategy, 3(2), 25-32.

Kock, N., \& Hadaya, P. (2018). Minimum sample size estimation in PLS-SEM: The inverse square root and gamma-exponential methods. Information Systems Journal, 28(1), 227-261.

Kutlu, B. (2008). The usage and adoption of it among SMEs in Turkey.

Lankshear, C., \& Knobel, M. (2008). Digital literacies: Concepts, policies and practices (30). Peter Lang Publishing.

http://www.peterlang.com/index.cfm?event=cmp.ccc.seitenstruktur.detailseiten\&seitentyp $=$ produkt $\&$ pk $=50663 \&$ cid $=5 \&$ concordeid $=310168$

Lebas, M. J. (1995). Performance measurement and performance management. International Journal of Production Economics, 41(1-3), 23-35.

Lennon, M., Kirsch, I., Von Davier, M., Wagner, M., \& Yamamoto, K. (2003). Feasibility study for the PISA ICT literacy assessment: Report to network A. In Educational Testing Service. Educational Testing Service. https://eric.ed.gov/?id=ED504154

Liang, T., You, J., \& Liu, C. (2010). A resource-based perspective on information technology and firm performance: A meta analysis. Industrial Management \& Data Systems, 110(8), 1138-1158. https://doi.org/10.1108/02635571011077807

Mithas, S., Tafti, A., Bardhan, I., \& Mein, G. (2012). Information technology and firm profitability. MIS Quarterly, 36(1), 205-224.

Morgan, C. (2004). Structure, speed and salience: Performance measurement in the supply chain. Business Process Management Journal, 10(5), 522-536. https://doi.org/10.1108/14637150410559207

Neely, A. (2005). The evolution of performance measurement research: Developments in the last decade and a research agenda for the next. International Journal of Operations \& Production Management, 25(12), 1264-1277. https://doi.org/10.1108/01443570510633648

Noorderhaven, N. G. (1996). Opportunism and trust in transaction cost economics. In J. Groenewegen (Ed.), Transaction Cost Economics and Beyond (pp. 105-128). Springer Netherlands. https://doi.org/10.1007/978-94-009-1800-9_6

Nooteboom, B. (1992). Information technology, transaction costs and the decision to "make or buy." Technology Analysis \& Strategic Management, 4(4), 339-350.

https://doi.org/10.1080/09537329208524105

Nooteboom, B. (1993). Firm size effects on transaction costs. Small Business Economics, 5(4), 283295. https://doi.org/10.1007/BF01516249

Olawale, F. (2018). The impact of entrepreneurial resilience on the success of small and medium enterprises in South Africa. Sustainability, 10(7), 1-12.

O’Regan, N., \& Ghobadian, A. (2004). Strategic planning: The kkey to enhanced performance? In A. Ghobadian, N. O’Regan, D. Gallear, \& H. Viney (Eds.), Strategy and Performance: Achieving 
INTERNATIONAL JOURNAL OF ACADEMIC RESEARCH IN BUSINESS AND SOCIAL SCIENCES

Vol. 10, No. 5, May, 2020, E-ISSN: 2222-6990 @ 2020 HRMARS

Competitive Advantage in the Global Marketplace (pp. 132-161). Palgrave Macmillan UK. https://doi.org/10.1057/9780230523135_7

Organization of Economic Co-operation and Development (OECD). (2017). Enhancing the contributions of SMEs in a global and digitalised economy. Meeting of the OECD Council at Ministerial Level. Retrieved from https:// www.oecd.org/mcm/documents/C-MIN-2017-8EN.pdf

Perren, L. (2000). Factors in the growth of micro-enterprises (Part 2): Exploring the implications. Journal of Small Business and Enterprise Development, 7(1), 58-68. https://doi.org/10.1108/EUM0000000006805

Pham, Q. T. (2010). Measuring the ICT maturity of SMEs. Journal of Knowledge Management Practice, 11(1).

Pham, X. K., Son, L. N., \& Giang, N. T. P. (2013). Measuring the ICT maturity of enterprises under uncertainty using group fuzzy ANP. International Journal of Machine Learning and Computing, 3(6), 524-528. https://doi.org/10.7763/IJMLC.2013.V3.374

Pool, C. R. (1997). A new digital literacy: A conversation with Paul Gilster. Educational Leadership, 55(3), 6-11.

Poppo, L., \& Zenger, T. (1998). Testing alternative theories of the firm: Transaction cost, knowledgebased, and measurement explanations for make-or-buy decisions in information services. Strategic Management Journal, 19(9), 853-877. https://doi.org/10.1002/(SICI)10970266(199809)19:9<853::AID-SMJ977>3.0.CO;2-B

Porter, M. E. (1980). Competitive strategy. New York Free Press.

Priyanath, H. M. S. (2017). Effect of Information access through social capital on mitigating business opportunism of small enterprises in Sri Lanka. Colombo Business Journal, 8(2), 42-67.

Priyanath, H. M. S., \& Buthsala, A. (2017). Information, opportunism and business performance: A case of small businesses managed by women entrepreneurs in Sri Lanka. Asian Journal of Multidisciplinary Studies, 5(11), 230-239.

Priyanath, H. M. S., \& Premarathne, S. P. (2014). Government SME development programs in Sri Lanka: A review in the lens of transaction cost economics. Sabaragamuwa University Journal, 13(2), 59-81.

Priyanath, H. M. S., \& Premarathne, S. P. (2015). Effect of social capital on transaction cost: A multiple case study of small enterprises in Sri Lanka. International Journal of Arts and Commerce, 4(4), 127-138.

Priyanath, H. M. S., \& Premaratne, S. P. (2017a). Power of social capital on mitigating transaction cost of small enterprises in Sri Lanka: An Empirical Investigation. International Journal of Arts and Commerce, 6(4), 17-35.

Priyanath, H. M. S., \& Premaratne, S. P. (2017b). The effect of inter-personal trusts on transaction costs of owner-managed small enterprises in Sri Lanka. Economic Research, 5, 1.

Priyanto, E., Maryunani, M., Mazkie, G., \& Khusaini, M. (2014). Effects of asymmetric information, transaction cost to corporate governance, and public organization performance (Study In Local water company in Malang Regency). IOSR Journal of Business and Management, 15(6), 14-27. https://doi.org/10.9790/487X-1561427

Ranatunga, R. V. S. P. K., Priyanath, H. M. S., \& Megama, R. G. N. (2020). Methods and rule-of-thumbs in the determination of minimum sample size when appling structural equation modelling: $A$ 
INTERNATIONAL JOURNAL OF ACADEMIC RESEARCH IN BUSINESS AND SOCIAL SCIENCES

Vol. 10, No. 5, May, 2020, E-ISSN: 2222-6990 @ 2020 HRMARS

review. JOURNAL OF SOCIAL SCIENCE RESEARCH, 15, 102-109. https://doi.org/10.24297/jssr.v15i.8670

Richard, P. J., Devinney, T. M., Yip, G. S., \& Johnson, G. (2009). Measuring organizational performance: Towards methodological best practice: Journal of Management. https://doi.org/10.1177/0149206308330560

Rindfleisch, A., \& Heide, J. B. (1997). Transaction cost analysis: Past, present, and future applications. Journal of Marketing Research, 61(4), 30-54.

Robson, C. (2002). Real world research (2nd ed.). Oxford: Blackwel.

Santos, J. B., \& Brito, L. A. L. (2012). Toward a subjective measurement model for firm performance. BAR - Brazilian Administration Review, 9, 95-117. https://doi.org/10.1590/S180776922012000500007

Shin, H. D. (2003). The role of uncertainty in transaction cost and resource-based theories of the firm [PhD Dissertation]. Graduate School of the Ohio State University.

Simpson, M., Tuck, N., \& Bellamy, S. (2004). Small business success factors: The role of education and training. Education $+\quad$ Training, 46(8/9), https://doi.org/10.1108/00400910410569605

Thatcher, R. W. (2010). Validity and reliability of quantitative electroencephalography. Journal of Neurotherapy, 14(2), 122-152. https://doi.org/10.1080/10874201003773500

Walker, E., \& Brown, A. (2016). What success factors are important to small business owners?: International Small Business Journal. https://doi.org/10.1177/0266242604047411

Wholey, J. S. (1996). Formative and summative evaluation: Related issues in performance measurement. Evaluation Practice, 17(2), 145-149. https://doi.org/10.1016/S08861633(96)90019-7

Williamson, O. E. (1975). Markets and hierarchies: Analysis and antitrust implications: A study in the economics of internal organization (SSRN Scholarly Paper ID 1496220). Social Science Research Network. https://papers.ssrn.com/abstract=1496220

Williamson, O. E. (1985). The economic institutions of capitalism: Firms, markets, relational contracting. New York: Free Press; London: Collier Macmillan. https://trove.nla.gov.au/version/45242907

Yenidogan, T. G. (2013). The impact of transaction attributes and trust on ex-post opportunism (SSRN Scholarly Paper ID 2712063). Social Science Research Network. https://papers.ssrn.com/abstract=2712063

Yoshino, N., \& Taghizadeh-Hesary, F. (2016). Major challenges facing small and medium-sized enterprises in Asia and solutions for mitigating them (Issue 564). Asian Development Bank. https://www.adb.org/publications/major-challenges-facing-small-and-medium-sizedenterprises-asia-and-solutions

Yousuf, A. (2017). Transaction costs: A conceptual framework. International Journal of Engineering and Management Sciences (IJEMS), 2(3), 131-139. https://doi.org/DOI: 10.21791/IJEMS.2017.3.13

Zhu, Q., \& Sarkis, J. (2004). Relationships between operational practices and performance among early adopters of green supply chain management practices in Chinese manufacturing enterprises. Journal of Operations Management, 22(3), 265-289. https://doi.org/10.1016/j.jom.2004.01.005 
INTERNATIONAL JOURNAL OF ACADEMIC RESEARCH IN BUSINESS AND SOCIAL SCIENCES Vol. 10, No. 5, May, 2020, E-ISSN: 2222-6990 @ 2020 HRMARS

Zimmermann, F., \& Foerstl, K. (2014). A meta-analysis of the "purchasing and supply management practice-performance link." Journal of Supply Chain Management, 50(3), 37-54. https://doi.org/10.1111/jscm.12051 
INTERNATIONAL JOURNAL OF ACADEMIC RESEARCH IN BUSINESS AND SOCIAL SCIENCES

Vol. 10, No. 5, May, 2020, E-ISSN: 2222-6990 @ 2020 HRMARS

Appendix I: Analysis of the First Order Constructs

\begin{tabular}{|c|c|c|c|c|c|c|}
\hline \multicolumn{2}{|r|}{ Construct } & Loading & t- Statistics & CR & AVE & $\alpha^{*}$ \\
\hline \multirow[t]{8}{*}{1} & \multicolumn{3}{|l|}{ Economic Performance Customer Satisfaction } & \multirow[t]{8}{*}{0.920} & \multirow[t]{8}{*}{0.624} & \multirow[t]{8}{*}{0.898} \\
\hline & Customer feedback on our production & 0.853 & 25.86 & & & \\
\hline & $\begin{array}{l}\text { Changes of production according to the } \\
\text { customer feedback }\end{array}$ & 0.789 & 9.70 & & & \\
\hline & $\begin{array}{l}\text { Introduce new production according to the } \\
\text { customer requests }\end{array}$ & 0.746 & 9.90 & & & \\
\hline & $\begin{array}{l}\text { Growth of Number of customers in each } \\
\text { marketing area }\end{array}$ & 0.883 & 31.54 & & & \\
\hline & $\begin{array}{l}\text { Complaints on the production(s) receive from } \\
\text { customers }\end{array}$ & 0.700 & 11.27 & & & \\
\hline & The frequency of returning items & 0.752 & 14.31 & & & \\
\hline & Growth of popularity of the tradename & 0.789 & 24.34 & & & \\
\hline \multirow[t]{6}{*}{2} & \multicolumn{3}{|l|}{ Economic Performance Employee Satisfaction } & \multirow[t]{6}{*}{0.911} & \multirow[t]{6}{*}{0.672} & \multirow[t]{6}{*}{0.876} \\
\hline & Growth of expenditure for training programs & 0.859 & 34.20 & & & \\
\hline & $\begin{array}{l}\text { Growth of providing gift and bonus for the } \\
\text { employee }\end{array}$ & 0.834 & 19.26 & & & \\
\hline & Decrement of resignation & 0.820 & 22.39 & & & \\
\hline & Increment of employee salary & 0.873 & 33.27 & & & \\
\hline & Increment of employee welfare & 0.711 & 11.69 & & & \\
\hline \multirow[t]{3}{*}{3} & \multicolumn{3}{|l|}{ Economic performance Environmental } & \multirow[t]{3}{*}{0.888} & \multirow[t]{3}{*}{0.798} & \multirow[t]{3}{*}{0.749} \\
\hline & Policy on environmental protection & 0.877 & 5.700 & & & \\
\hline & $\begin{array}{l}\text { Improvement of the production to enhance the } \\
\text { environment protection }\end{array}$ & 0.909 & 10.36 & & & \\
\hline \multirow[t]{4}{*}{4} & \multicolumn{3}{|l|}{ Economic Performance Growth } & \multirow[t]{4}{*}{0.852} & \multirow[t]{4}{*}{0.658} & \multirow[t]{4}{*}{0.736} \\
\hline & Opening of new factory & 0.825 & 18.52 & & & \\
\hline & Increment of number of employees & 0.729 & 19.88 & & & \\
\hline & Establishing new buildings & 0.874 & 32.26 & & & \\
\hline \multirow[t]{6}{*}{5} & \multicolumn{3}{|l|}{ Economic Performance Profit } & \multirow[t]{6}{*}{0.9402} & \multirow[t]{6}{*}{0.759} & \multirow[t]{6}{*}{0.919} \\
\hline & Growth of monthly sales volume & 0.912 & 48.83 & & & \\
\hline & Growth of monthly income & 0.840 & 23.13 & & & \\
\hline & Growth of profit & 0.923 & 46.14 & & & \\
\hline & Decrement of sold product returning volume & 0.786 & 16.08 & & & \\
\hline & Increment of stock movement & 0.890 & 35.55 & & & \\
\hline \multirow[t]{3}{*}{6} & Economic Performance Social & & & \multirow[t]{3}{*}{0.8322} & \multirow[t]{3}{*}{0.714} & \multirow[t]{3}{*}{0.619} \\
\hline & $\begin{array}{l}\text { Allocation of job opportunities for employees } \\
\text { who represent less income group }\end{array}$ & 0.921 & 31.30 & & & \\
\hline & $\begin{array}{l}\text { Conducting social activities such as help to } \\
\text { disabilities, cultural events etc. }\end{array}$ & 0.762 & 8.66 & & & \\
\hline
\end{tabular}

*Cronbach's $\alpha$.

$(n=110)$.

Source: Survey data, 2020. 
INTERNATIONAL JOURNAL OF ACADEMIC RESEARCH IN BUSINESS AND SOCIAL SCIENCES Vol. 10, No. 5, May, 2020, E-ISSN: 2222-6990 @ 2020 HRMARS

Appendix II: Discriminant Validity of the First Order Constructs

\begin{tabular}{|l|l|l|l|l|l|l|}
\hline & EPCusSati & EPEmpSati & EPEnvi & EPGrowth & EPProfit & EPSocial \\
\hline EPCusSati & $\mathbf{0 . 7 8 9}$ & & & & & \\
\hline EPEmpSati & 0.783 & $\mathbf{0 . 8 1 9}$ & & & & \\
\hline EPEnvi & 0.232 & 0.250 & $\mathbf{0 . 8 9 3}$ & & & \\
\hline EPGrowth & 0.651 & 0.712 & 0.165 & $\mathbf{0 . 8 1 1}$ & & \\
\hline EPProfit & 0.772 & 0.709 & 0.145 & 0.608 & $\mathbf{0 . 8 7 1}$ & \\
\hline EPSocial & 0.478 & 0.597 & 0.179 & 0.471 & 0.473 & $\mathbf{0 . 8 4 5}$ \\
\hline
\end{tabular}

$(n=110)$

Source: Survey data 2020

Appendix III: Analysis of the Second Order Constructs

\begin{tabular}{|c|c|c|c|c|c|c|}
\hline \multicolumn{2}{|c|}{\begin{tabular}{|r|} 
Construct \\
\end{tabular}} & Loading & t- Statistics & CR & AVE & $\alpha^{*}$ \\
\hline \multirow[t]{5}{*}{1} & \multicolumn{3}{|l|}{ Economic Performance } & \multirow[t]{5}{*}{0.933} & \multirow[t]{5}{*}{0.779} & \multirow[t]{5}{*}{0.905} \\
\hline & Profit & 0.905 & 50.77 & & & \\
\hline & Growth & 0.911 & 54.30 & & & \\
\hline & Employee satisfaction & 0.849 & 33.41 & & & \\
\hline & Customer satisfaction & 0.864 & 38.92 & & & \\
\hline \multirow[t]{6}{*}{2} & \multicolumn{3}{|l|}{ Behavioral Uncertainty } & \multirow[t]{6}{*}{0.914} & \multirow[t]{6}{*}{0.681} & \multirow[t]{6}{*}{0.885} \\
\hline & $\begin{array}{l}\text { Buyers do not provide clear information when } \\
\text { doing transactions }\end{array}$ & 0.842 & 34.34 & & & \\
\hline & $\begin{array}{l}\text { Buyers make changes on the agreements to } \\
\text { obtain more benefits }\end{array}$ & 0.881 & 47.97 & & & \\
\hline & Buyers are not sincere in transaction activities. & 0.828 & 19.00 & & & \\
\hline & Buyers do not fair in transaction activities & 0.786 & 15.88 & & & \\
\hline & $\begin{array}{l}\text { High risk of opportunistic behavior of the } \\
\text { buyers. }\end{array}$ & 0.783 & 15.14 & & & \\
\hline \multirow[t]{9}{*}{3} & \multicolumn{3}{|l|}{ Digital Literacy Applications } & \multirow[t]{9}{*}{0.933} & \multirow[t]{9}{*}{0.610} & \multirow[t]{9}{*}{0.920} \\
\hline & $\begin{array}{l}\text { Use voice or video call application over the } \\
\text { internets (WhatsApp, Viber) }\end{array}$ & 0.809 & 19.72 & & & \\
\hline & $\begin{array}{l}\text { Use social media like Facebook for business } \\
\text { purposes }\end{array}$ & 0.781 & 19.51 & & & \\
\hline & Use Management Information Systems & 0.760211 & 14.53 & & & \\
\hline & Organization has e-Mail address & 0.781 & 16.01 & & & \\
\hline & $\begin{array}{l}\text { Handle business activities using standard } \\
\text { applications such as MS office with the } \\
\text { computers }\end{array}$ & 0.820 & 25.88 & & & \\
\hline & $\begin{array}{l}\text { Use e-marketing applications such as web } \\
\text { advertisements etc. }\end{array}$ & 0.725 & 11.68 & & & \\
\hline & $\begin{array}{l}\text { Use e-Banking/e-money applications for } \\
\text { business purposes }\end{array}$ & 0.758 & 12.82 & & & \\
\hline & Use Databases and knowledge bases & 0.790 & 18.35 & & & \\
\hline
\end{tabular}


INTERNATIONAL JOURNAL OF ACADEMIC RESEARCH IN BUSINESS AND SOCIAL SCIENCES Vol. 10, No. 5, May, 2020, E-ISSN: 2222-6990 @ 2020 HRMARS

\begin{tabular}{|c|c|c|c|c|c|c|}
\hline & $\begin{array}{l}\text { Use customized software for handling } \\
\text { business functions }\end{array}$ & 0.802 & 24.25 & & & \\
\hline \multirow[t]{10}{*}{4} & \multicolumn{3}{|l|}{ Digital Literacy Human Resources } & \multirow[t]{10}{*}{0.967} & \multirow[t]{10}{*}{0.769} & \multirow[t]{10}{*}{0.962} \\
\hline & Employees have IT knowledge & 0.903 & 41.13 & & & \\
\hline & Recruiting specialized IT persons & 0.835 & 30.27 & & & \\
\hline & $\begin{array}{l}\text { Employees can use internet \& it's } \\
\text { services }\end{array}$ & 0.850 & 28.08 & & & \\
\hline & Employees use Internet Messaging or e-mails & 0.912 & 38.92 & & & \\
\hline & $\begin{array}{l}\text { Employees do video conferencing for business } \\
\text { activities }\end{array}$ & 0.898 & 43.63 & & & \\
\hline & $\begin{array}{l}\text { Employees use internet and knowledge bases } \\
\text { like YouTube for business problems }\end{array}$ & 0.859 & 32.29 & & & \\
\hline & $\begin{array}{l}\text { Owner can obtain new knowledge through the } \\
\text { Internet }\end{array}$ & 0.868 & 33.79 & & & \\
\hline & Decision making using MIS & 0.833 & 25.35 & & & \\
\hline & $\begin{array}{l}\text { Employees can use computers and related } \\
\text { equipment's }\end{array}$ & 0.927 & 75.81 & & & \\
\hline \multirow[t]{9}{*}{5} & \multicolumn{3}{|l|}{ Digital Literacy Infrastructure } & \multirow[t]{9}{*}{0.958} & \multirow[t]{9}{*}{0.742} & \multirow[t]{9}{*}{0.949} \\
\hline & $\begin{array}{l}\text { Use fixed line telephone for business } \\
\text { purposes. }\end{array}$ & 0.907 & 40.98 & & & \\
\hline & Use mobile phones for business purposes. & 0.949 & 85.46 & & & \\
\hline & Use local area network & 0.761 & 25.07 & & & \\
\hline & $\begin{array}{l}\text { Use other peripherals like POS, barcode } \\
\text { readers, fax machines, photocopy/scanner } \\
\text { machines etc. }\end{array}$ & 0.849 & 21.58 & & & \\
\hline & Use computers to handle business functions. & 0.893 & 36.36 & & & \\
\hline & Has Broadband internet access and Wifi & 0.842 & 20.04 & & & \\
\hline & $\begin{array}{l}\text { Use servers for information handling (hosting } \\
\text { website, database, etc.) }\end{array}$ & 0.791 & 29.03 & & & \\
\hline & $\begin{array}{l}\text { Use portable devices with a mobile Internet } \\
\text { connection }\end{array}$ & 0.884 & 34.17 & & & \\
\hline \multirow[t]{7}{*}{6} & \multicolumn{3}{|l|}{ Digital Literacy Policy } & \multirow[t]{7}{*}{0.950} & \multirow[t]{7}{*}{0.760} & \multirow[t]{7}{*}{0.937} \\
\hline & $\begin{array}{l}\text { Investment for digital technology } \\
\text { development }\end{array}$ & 0.845 & 27.00 & & & \\
\hline & $\begin{array}{l}\text { Assess the digital infrastructure on regular } \\
\text { time }\end{array}$ & 0.835 & 18.62 & & & \\
\hline & Security policy & 0.884 & 23.60 & & & \\
\hline & Followed rules and regulations & 0.896 & 29.98 & & & \\
\hline & Employee training as a policy & 0.857 & 20.08 & & & \\
\hline & Updating software and hardware & 0.910 & 49.00 & & & \\
\hline \multirow[t]{3}{*}{7} & \multicolumn{3}{|l|}{ Environmental Uncertainty } & \multirow[t]{3}{*}{0.968} & \multirow[t]{3}{*}{0.814} & \multirow[t]{3}{*}{0.961} \\
\hline & Capability to forecast the market shares & 0.822 & 19.42 & & & \\
\hline & Capability to forecast the future sales volume & 0.923 & 45.50 & & & \\
\hline
\end{tabular}


INTERNATIONAL JOURNAL OF ACADEMIC RESEARCH IN BUSINESS AND SOCIAL SCIENCES Vol. 10, No. 5, May, 2020, E-ISSN: 2222-6990 @ 2020 HRMARS

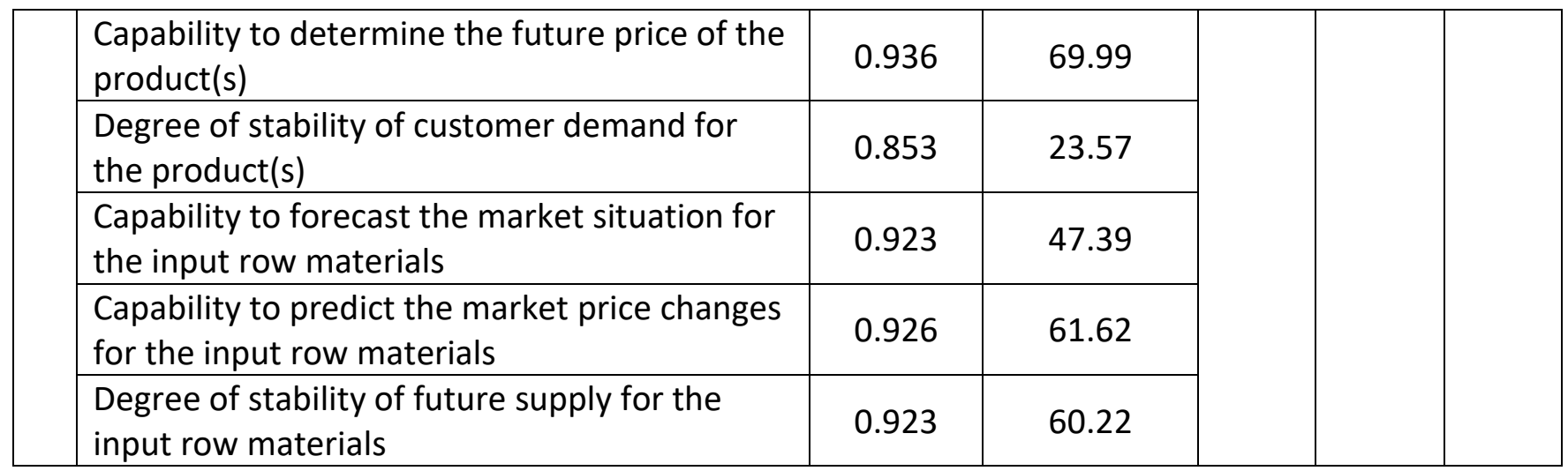

$(n=110)$.

Source: Survey data, 2020.

Appendix IV: Discriminant Validity of the Second Order Constructs

\begin{tabular}{|l|l|l|l|l|l|l|l|}
\hline & EP & DLAppli & DLHR & DLInfra & DLPolicy & UnBehe & UnEnvi \\
\hline EP & $\mathbf{0 . 8 8 3}$ & & & & & & \\
\hline DLAppli & 0.676 & $\mathbf{0 . 7 8 1}$ & & & & & \\
\hline DLHR & 0.736 & 0.608 & $\mathbf{0 . 8 7 7}$ & & & & \\
\hline DLInfra & 0.720 & 0.588 & 0.764 & $\mathbf{0 . 8 6 2}$ & & & \\
\hline DLPolicy & 0.515 & 0.494 & 0.391 & 0.444 & $\mathbf{0 . 8 7 2}$ & & \\
\hline UnBehe & -0.643 & -0.467 & -0.547 & -0.498 & -0.239 & $\mathbf{0 . 8 2 5}$ & \\
\hline UnEnvi & -0.703 & -0.554 & -0.691 & -0.589 & -0.386 & 0.556 & $\mathbf{0 . 9 0 2}$ \\
\hline
\end{tabular}

$(n=110)$

Source: Survey data 2020

Appendix V: Assess Structural Model for Collinearity Issues of Model 01

\begin{tabular}{|c|c|c|c|c|c|c|c|c|}
\hline \multicolumn{9}{|c|}{ Coefficients $^{a}$} \\
\hline \multirow{2}{*}{\multicolumn{2}{|c|}{ Model }} & \multicolumn{2}{|c|}{$\begin{array}{c}\text { Unstandardized } \\
\text { Coefficients }\end{array}$} & \multirow{2}{*}{$\begin{array}{c}\text { Standardize } \\
d \\
\text { Coefficients } \\
\text { Beta }\end{array}$} & \multirow[b]{2}{*}{$t$} & \multirow[b]{2}{*}{ Sig. } & \multicolumn{2}{|c|}{ Collinearity Statistics } \\
\hline & & B & Std. Error & & & & $\begin{array}{c}\text { Toleranc } \\
\text { e }\end{array}$ & VIF \\
\hline \multirow[t]{7}{*}{1} & (Constant) & $-1.935 \mathrm{E}-6$ & .050 & & .000 & 1.000 & & \\
\hline & DLAppli & .173 & .070 & .173 & 2.460 & .016 & .510 & 1.960 \\
\hline & DLHR & .158 & .090 & .158 & 1.749 & .083 & .311 & 3.220 \\
\hline & DLInfra & .204 & .082 & .204 & 2.481 & .015 & .374 & 2.671 \\
\hline & DLPolicy & .147 & .060 & .147 & 2.465 & .015 & .709 & 1.411 \\
\hline & UnBehe & -.233 & .064 & -.233 & -3.643 & .000 & .617 & 1.621 \\
\hline & UnEnvi & -.192 & .074 & -.192 & -2.581 & .011 & .454 & 2.201 \\
\hline
\end{tabular}

$(n=110)$

Source: Survey data 2020 
INTERNATIONAL JOURNAL OF ACADEMIC RESEARCH IN BUSINESS AND SOCIAL SCIENCES Vol. 10, No. 5, May, 2020, E-ISSN: 2222-6990 ㄷ 2020 HRMARS

Appendix VI: Assess Structural Model for Goodness-of-Fit Indices of Model 01

\begin{tabular}{|c|c|}
\hline & R Square \\
\hline EP & 0.740341 \\
\hline UnBehe & 0.337753 \\
\hline UnEnvi & 0.512433 \\
\hline
\end{tabular}

Assess the Effect Sizes - $f^{2}$

\begin{tabular}{|c|c|c|c|c|c|c|}
\hline $\begin{array}{l}\text { Independent } \\
\text { Construct }\end{array}$ & $\begin{array}{l}\mathbf{R}^{2} \\
\text { Included }\end{array}$ & $\begin{array}{l}\mathbf{R}^{2} \\
\text { excluded }\end{array}$ & $\begin{array}{c}A= \\
{\left[\left(R^{2} \text { Included }\right)-\right.} \\
\left.\left(R^{2} \text { excluded }\right)\right]\end{array}$ & $\begin{array}{l}\quad B= \\
1-\left(R^{2}\right. \\
\text { Included }) \\
\end{array}$ & $\begin{array}{c}\left(f^{2}\right) \\
(A / B)\end{array}$ & $\begin{array}{c}\text { Effect } \\
\text { Size }\end{array}$ \\
\hline \multicolumn{7}{|l|}{ BIQ } \\
\hline DLAppli & \multirow{6}{*}{0.740} & 0.459 & 0.281 & \multirow{6}{*}{0.260} & 1.08 & Large \\
\hline DLHR & & 0.543 & 0.197 & & 0.75 & Large \\
\hline DLInfra & & 0.526 & 0.214 & & 0.82 & Large \\
\hline DLPolicy & & 0.268 & 0.427 & & 1.64 & Large \\
\hline UnBehe & & 0.415 & 0.321 & & 1.23 & Large \\
\hline UnEnvi & & 0.495 & 0.245 & & 1.90 & Large \\
\hline
\end{tabular}

( $n=110)$

Source: Survey data 2020

Appendix VII Data Analysis of Model 02

Analysis of the Third Order Constructs

\begin{tabular}{|c|c|c|c|c|c|c|}
\hline \multirow{6}{*}{1} & Construct & Loading & t- Statistics & CR & AVE & $\boldsymbol{\alpha}^{*}$ \\
\hline & \multicolumn{3}{|l|}{ Economic Performance } & \multirow{5}{*}{0.934} & \multirow{5}{*}{0.779} & \multirow{5}{*}{0.906} \\
\hline & Customer Satisfaction & 0.909 & 0.770 & & & \\
\hline & Employee Satisfaction & 0.875 & 0.777 & & & \\
\hline & Growth & 0.934 & 0.779 & & & \\
\hline & Profit & 0.909 & 0.770 & & & \\
\hline \multirow[t]{3}{*}{2} & Uncertainty & & & \multirow{3}{*}{0.875} & \multirow{3}{*}{0.777} & \multirow{3}{*}{0.715} \\
\hline & Behavioral Uncertainty & 0.934 & 0.779 & & & \\
\hline & Environmental & 0.909 & 0.770 & & & \\
\hline \multirow[t]{4}{*}{3} & Digital Literacy & & & \multirow{4}{*}{0.875} & \multirow{4}{*}{0.777} & \multirow{4}{*}{0.850} \\
\hline & Applications & 0.823 & 20.785 & & & \\
\hline & Human resources & 0.910 & 60.844 & & & \\
\hline & Infrastructure & 0.896 & 51.793 & & & \\
\hline
\end{tabular}

$(\mathrm{n}=110)$

Source: Survey data 2020

Discriminant Validity of the Third Order Constructs

\begin{tabular}{|c|c|c|c|}
\hline & EP & Digital Literacy & Business Uncertainty \\
\hline EP & $\mathbf{0 . 8 8 3}$ & & \\
\hline Digital Literacy & 0.810 & $\mathbf{0 . 8 7 8}$ & \\
\hline Uncertainty & -0.765 & -0.727 & $\mathbf{0 . 8 8 2}$ \\
\hline
\end{tabular}


INTERNATIONAL JOURNAL OF ACADEMIC RESEARCH IN BUSINESS AND SOCIAL SCIENCES Vol. 10, No. 5, May, 2020, E-ISSN: 2222-6990 @ 2020 HRMARS

\section{Assess Structural Model for Collinearity Issues of Model 02}

\begin{tabular}{|c|c|c|c|c|c|c|c|c|}
\hline \multicolumn{9}{|c|}{ Coefficients $^{\mathrm{a}}$} \\
\hline & & \multicolumn{2}{|c|}{$\begin{array}{c}\text { Unstandardized } \\
\text { Coefficients }\end{array}$} & \multirow{2}{*}{$\begin{array}{c}\begin{array}{c}\text { Standardize } \\
\mathrm{d} \\
\text { Coefficients }\end{array} \\
\text { Beta }\end{array}$} & \multirow[b]{2}{*}{$\mathrm{t}$} & \multirow[b]{2}{*}{ Sig. } & \multicolumn{2}{|c|}{$\begin{array}{c}\text { Collinearity } \\
\text { Statistics }\end{array}$} \\
\hline \multicolumn{2}{|c|}{ Model } & B & Std. Error & & & & $\begin{array}{c}\text { Toleranc } \\
\mathrm{e}\end{array}$ & VIF \\
\hline 1 & (Constant) & $\begin{array}{r}-5.535 E- \\
6 \\
\end{array}$ & .051 & & .000 & 1.000 & & \\
\hline & $\begin{array}{l}\text { Digital } \\
\text { Literacy }\end{array}$ & .539 & .074 & .539 & 7.254 & .000 & .471 & 2.121 \\
\hline & Uncertainty & -.373 & .074 & -.373 & -5.025 & .000 & .471 & 2.121 \\
\hline
\end{tabular}

